\title{
Feeding ecology of American sand lance Ammodytes americanus larvae from Long Island Sound ${ }^{*}$
}

\author{
Doreen M. Monteleone \& William T. Peterson \\ Marine Sciences Research Center, State University of New York, Stony Brook, New York 11794-5000, USA
}

\begin{abstract}
Sand lance larvae consumed phytoplankton and various developmental stages of the copepods Temora longicornis, Acartia hudsonica and Pseudocalanus sp. Their diet changed with ontogeny: small larvae consumed phytoplankton and larger larvae ate copepods of increasingly older developmental stages. Samples taken during daylight indicated that the larvae have a gut capacity of approximately $0.56 \%$ of their body dry weight. Laboratory studies conducted with live larvae indicated non-selective feeding on copepod nauplii, but in the field, Ivlev indices indicated selection for $T$ longicornis nauplii and against $A$. hudsonica nauplii. Larger larvae selected for $T$ longicornis copepodites and against A. hudsonica copepodites and females, but as they approach metamorphosis, they began to select for $A$. hudsonica females. The feeding behavior of small larvae is passive, but becomes more aggressive as the larvae mature. Biomass consumed increased with increased prey density and water temperature. Clearance rates for larvae at $7^{\circ} \mathrm{C}$ in the laboratory were $0.02,0.05,0.48$ and $3.2 \mathrm{l} \mathrm{d}^{-1}$ for 4.5 to $5.0,6$ to $7.0,10$ to 11.0 , and $21 \mathrm{~mm}$ larvae, respectively. Calculations of the predatory impact of sand lance larvae on copepod nauplii indicate that they are insignificant consumers taking a maximum of $13.4 \%$ of the copepod production per day.
\end{abstract}

\section{INTRODUCTION}

There is an important predator-prey relation between larval fish and zooplankton. In order to fully understand this interaction it is important to determine the species composition of the larval diet, the availability of the prey, and the feeding rate of the larvae in relation to prey density and environmental conditions. Combining this information with field estimates of larval and prey density, one can estimate the impact larvae have on the population dynamics of the prey species.

This paper describes the feeding ecology of larvae of the American sand lance Ammodytes americanus in relation to its food supply in Long Island Sound. This species was chosen because it is the most abundant fish larva in the Sound during the winter, comprising over $85 \%$ of the ichthyoplankton (Monteleone 1984). Sand lance larvae are present in the Sound from late November through May, during which period the water temperature ranges from -1 to $10^{\circ} \mathrm{C}$ (Mon-

- Contribution No. 514, Marine Sciences Research Center teleone 1984). Larvae are 3 to $4 \mathrm{~mm}$ at hatching (Richards 1965) and complete metamorphosis by 30 to $40 \mathrm{~mm}$ (Reay 1970). During their larval history in Long Island Sound, prey availability ranges from low density conditions in December through a time of maximum zooplankton densities during February through April.

In this paper we discuss various aspects of the feeding ecology of sand lance larvae including a description of their diets, feeding environment, density and growth. Feeding selectivity, feeding behavior and ingestion rates were also examined in the laboratory. Finally, estimates were made of their potential impact on the zooplankton population in Long Island Sound.

\section{MATERIALS AND METHODS}

Sand lance larvae were collected during daylight at 2 stations in central Long Island Sound (Fig. 1). Water depth at Stn A was $20 \mathrm{~m}$, and at Stn B, $37 \mathrm{~m}$. Samples were taken at Stn A from March through May 1982, and at B from March 1982 through May 1983. One tow 


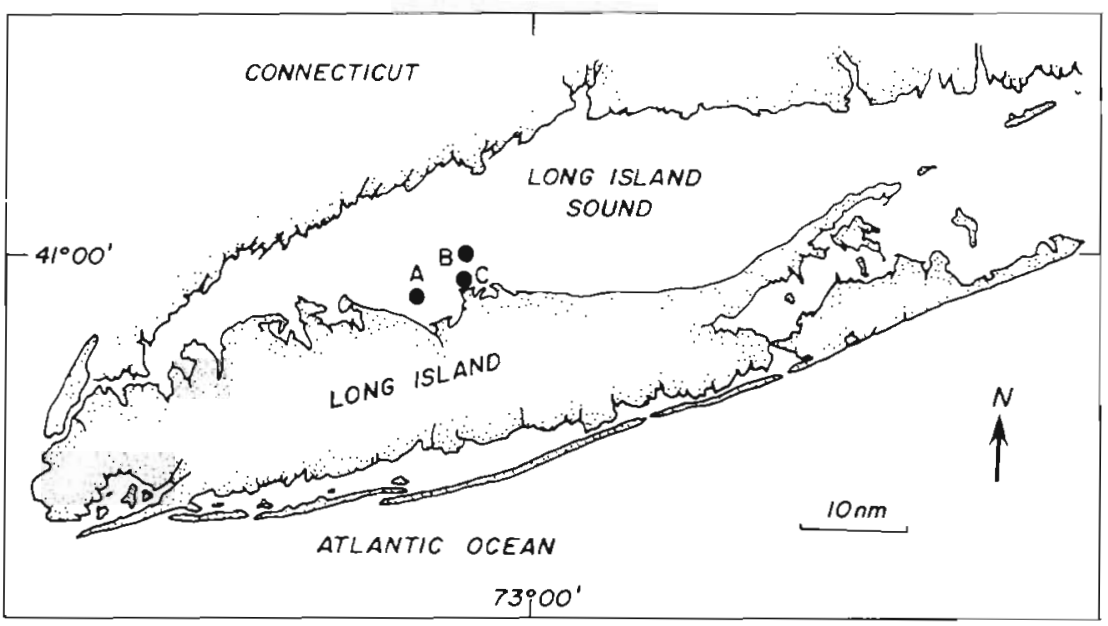

Fig. 1. Map of Long Island Sound. Stns $A$ and $B$ were sampled during 1982-83 and Stn C in 1985

was also taken at dawn on 8 May 1985 at Stn C. The larvae were collected with 0.75 and $1.0 \mathrm{~m}$ diameter plankton nets with 505 and $363 \mu \mathrm{m}$ mesh, respectively. Towing speed was 2 to 3 knots. TSK flow meters were employed to measure the volume of water filtered. In 1982, step oblique tows were taken at $A$ and $B$ by lowering the net to $10 \mathrm{~m}$ and then towing for $1 \mathrm{~min}$ at $1 \mathrm{~m}$ intervals to the surface. Tows were taken for $5 \mathrm{~min}$ at discrete depths of 0 to 1, 5, and $15 \mathrm{~m}$ at $\mathrm{Stn}$ B in 1983. All samples were preserved in 5 to $10 \%$ buffered formalin.

Temperature and salinity were measured at discrete depths of $1,3,5,10,15,20,30$, and $37 \mathrm{~m}$ at Stn B with a Beckman RS-5 Induction Salinometer. Water samples were taken at the same depths with a Jabsco Water Puppy pump and a $1.9 \mathrm{~cm}$ i.d. hose. From each depth $100 \mathrm{ml}$ was filtered through a GF/C filter for chlorophyll analysis, and 3 to 6 I were filtered through a $64 \mu \mathrm{m}$ Nitex screen and preserved in 5 to $10 \%$ buffered formalin for enumeration of copepod life stages.

All sand lance larvae were removed from the samples and densities estimated. The notochord length of prolarvae and standard length of postlarvae (both will be referred to as length) was measured to the nearest $0.1 \mathrm{~mm}$ under a dissecting microscope at $10 \times$. Fifty larvae (or the entire sample, whichever was smaller) were measured.

Dry weights of 35 randomly chosen, measured larvae were taken to obtain a length-weight relation. Larvae were placed on pre-weighed aluminum foil, and dried for a minimum of $24 \mathrm{~h}$ at $60^{\circ} \mathrm{C}$, then weighed on a Cahn Electrobalance to the nearest $0.1 \mu \mathrm{g}$.

Ten larvae from each sample (or the whole sample, whichever was smaller) were dissected for gut content analysis using a technique similar to Last's (1978). A total of 175 larvae were examined. The entire gut was separated from the larva by teasing it free with a dissecting pin, the gut was placed in glycerin, opened, and the contents identified and counted to species and stage of development. The total amount of food consumed was converted to dry weight by using dry weights of various developmental stages of prey items reported in Harris \& Paffenhöfer (1976), Durbin \& Durbin (1978), and Peterson (unpubl.). The gut contents were also compared to the prey items in the field and Ivlev (1961) electivity indices were calculated.

For laboratory studies of feeding rates, behavior, and feeding selectivity, larvae were collected with a $0.75 \mathrm{~m}$ diameter, $363 \mu \mathrm{m}$ plankton net and transported to the laboratory in an insulated container. Live zooplankton was collected with a $0.5 \mathrm{~m}$ diameter, $64 \mu \mathrm{m}$ mesh net and transported in a similar manner. The larvae were fed copepod nauplii and copepodites while maintained in 61 battery jars at temperatures of 2 and $7^{\circ} \mathrm{C}$ on a 10:14 light: dark cycle. During the feeding experiments, the larvae were kept individually in 200 to $1000 \mathrm{ml}$ glass containers with $64 \mu \mathrm{m}$ filtered seawater. The containers were covered on the sides and bottom with green or brown paper to simulate the dark background of their natural environment.

Selective feeding experiments were conducted in the laboratory by offering known numbers of Temora longicornis and Acartia hudsonica (formerly Acartia clausij) nauplii to individual larvae ranging from 7 to $11.5 \mathrm{~mm}$. After feeding for $24 \mathrm{~h}$, the larvae were removed from the containers, the remaining nauplii filtered from the water, preserved in $5 \%$ formalin and counted.

Feeding rates for larvae 4.5 to $21 \mathrm{~mm}$ long were determined in the laboratory. Larvae of size groups 4.5 to $5.0,6.0$ to 7.0 and 10.0 to $11.0 \mathrm{~mm}$ were placed individually into 200 and $1000 \mathrm{ml}$ containers with known numbers of a mixture of Temora longicornis and Acartia hudsonica nauplii (results showed neutral selection between species in the laboratory). A larger larva of $21 \mathrm{~mm}$ was fed known amounts of a mixture of nauplii, copepodites and adults of $T$. longicornis and 
A. hudsonica in 51 glass containers. After feeding for $24 \mathrm{~h}$, the larvae were removed, the remaining prey items filtered from the water, preserved in $5 \%$ formalin, and counted. The dry weight of food consumed was calculated.

The predatory impact sand lance larvae have on copepod populations was calculated from the formula:

$$
I=\sum_{i=m i n}^{i=\max } V_{1} N D_{i}
$$

where $\mathrm{I}=$ the total number of nauplii consumed each day by the sand lance larval population; $V=$ the volume cleared by a larva $\left(\mathrm{l} \mathrm{d}^{-1}\right) ; \mathrm{N}=$ the concentration of nauplii in the field (nauplii $\mathrm{l}^{-1}$ ); $\mathrm{D}=$ the density of the larvae in the field (no. $\mathrm{m}^{-3}$ ); $\mathrm{i}=1 \mathrm{~mm}$ intervals from the minimum to maximum length larva present.

\section{RESULTS}

\section{Density and growth of larvae}

Sand lance larvae were present in the water column from March 1982 when sampling began, through May 1982 and again from December 1982 through April 1983. The larvae were more abundant at 5 and $15 \mathrm{~m}$ and least abundant at the surface (Table 1). The monthly mean and range of standard lengths of sand lance larvae increased as the season progressed (Fig. 2). In December 1982 the larvae had a mean length of $5.8 \mathrm{~mm}$ (range 3 to $8 \mathrm{~mm}$ ). By April 1983, the mean length had increased to $18.6 \mathrm{~mm}$ (range 8 to $35 \mathrm{~mm}$. Small larvae were present from December through March, indicating that egg hatching occurs for several months.

Even though the hatching season is prolonged, most of the prolarvae were collected in December. A well defined cohort of larvae was evident during the 1982-83 growth season. Growth of the larvae was esti-

Table 1. Ammodytes americanus. Number of larvae per $\mathrm{m}^{3}$ at 3 depths during Jan, Mar and Apr 1983 at Stn B. - Densities $<0.005 \mathrm{~m}^{-1}$

\begin{tabular}{|c|c|c|c|}
\hline \multirow[t]{2}{*}{ Date } & \multicolumn{3}{|c|}{ Depth } \\
\hline & $1 \mathrm{~m}$ & $5 \mathrm{~m}$ & $15 \mathrm{~m}$ \\
\hline $12 \operatorname{Jan} 83$ & 1.20 & 3.58 & 3.41 \\
\hline 26 Jan 83 & • & 3.80 & 2.76 \\
\hline 3 Mar 83 & • & 0.60 & 0.30 \\
\hline 16 Mar 83 & 0.00 & 1.63 & 0.33 \\
\hline 24 Mar 83 & $\cdot$ & 0.82 & 0.30 \\
\hline 7 Apr 83 & 0.03 & 0.77 & 0.03 \\
\hline 11 Apr 83 & 0.57 & 0.02 & 0.05 \\
\hline 21 Арг 83 & 0.03 & 0.44 & 0.04 \\
\hline
\end{tabular}

mated from this cohort (Fig. 3). Because of prolonged hatching, monthly means were calculated using only the largest $25 \%$ of the larvae collected on a given date. This modification eliminated recently-hatched larvae, thus giving a more accurate measurement of growth rate. From December to January, the larvae grew $2.65 \mathrm{~mm}$; from January to March, $5.22 \mathrm{~mm}$ (or an average of $2.61 \mathrm{~mm} \mathrm{mo}^{-1}$ ); and from March to April, $6.88 \mathrm{~mm}$.
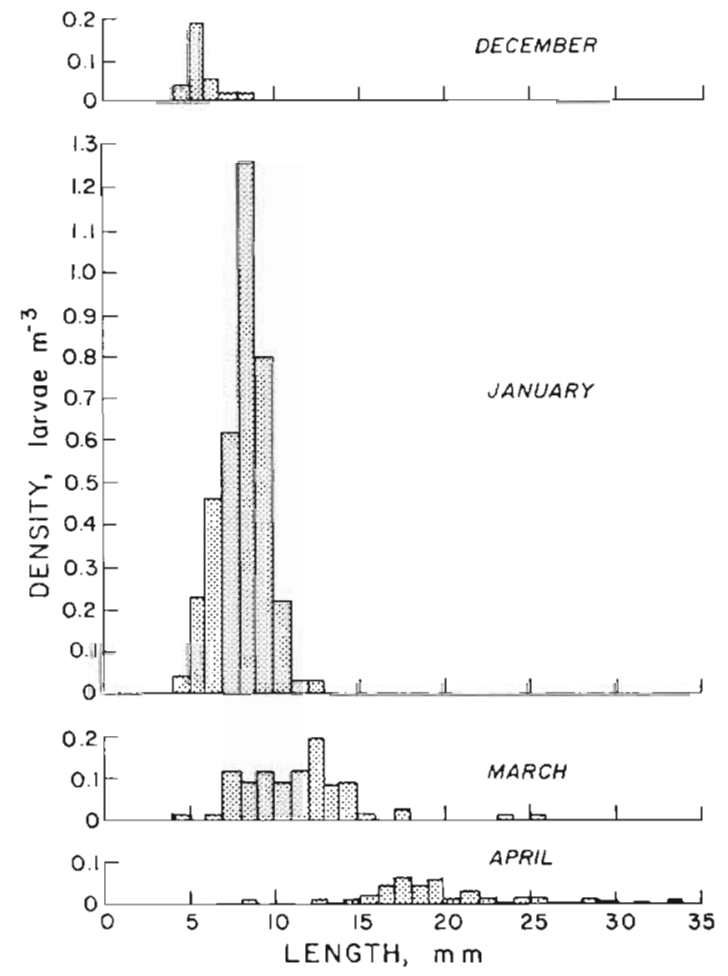

Fig. 2. Ammodytes americanus. Length-frequency distribution of larvae collected in oblique tows from 1 to $10 \mathrm{~m}$ during Dec 1982 and in horizontal tows at $5 \mathrm{~m}$ during Jan, Mar and Apr 1983 at Stn B

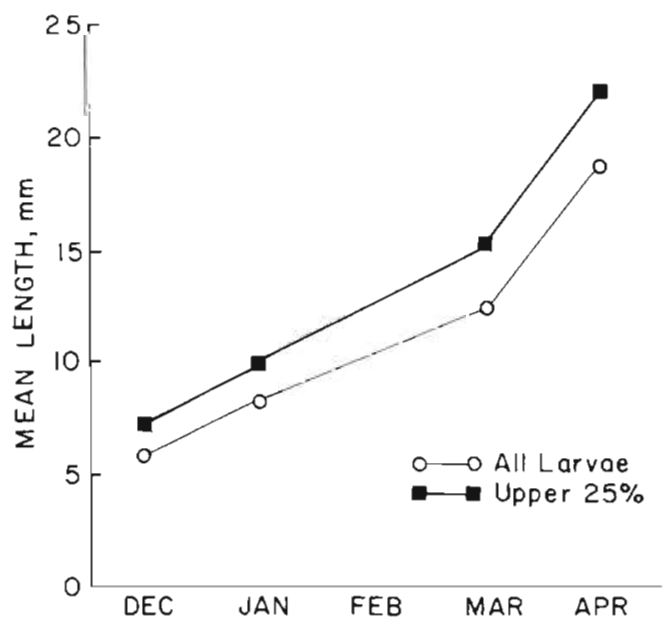

Fig. 3. Ammodytes americanus. Growth of larvae in length during winter and spring 1982-83 
The growth rate in terms of length was converted to dry weight using a length-weight formula derived from the length-weight relation illustrated in Fig. 4. The resulting formula was expressed as:

$$
\log W=2.91 \log L-0.245
$$

where $\mathrm{W}=$ dry weight of the larvae in $\| \mathrm{g} ; \mathrm{L}=$ length of the larvae in $\mathrm{mm}$. The growth of the largest $25 \%$ larvae, in $\mu \mathrm{g} \mathrm{d}^{-1}$, was 0.31 for December to January, 0.56 for January to March, and 5.20 for March to April. The instantaneous specific growth rates in terms of dry weight for these time periods were 0.03, 0.02 and $0.04 \mathrm{~d}^{-1}$.

\section{Feeding environment}

During the larval season, the water temperature ranges from approximately $10^{\circ} \mathrm{C}$ to probably a minimum of $0^{\circ} \mathrm{C}$ during February. The water column in Long Island Sound is isothermal from October through April (Peterson 1986). At the onset of the larval season in December, the larvae were abundant but their food enviromment was poor, containing limited amounts of both phytoplankton and zooplankton (Fig. 5). The spring bloom in Long Island Sound does not start until mid-February to mid-March (Fig. 5; Riley 1956, 1967, Riley \& Conover 1956, Vishniac \& Riley 1961, Peterson 1985). This bloom is followed approximately 1 mo later by a significant increase in

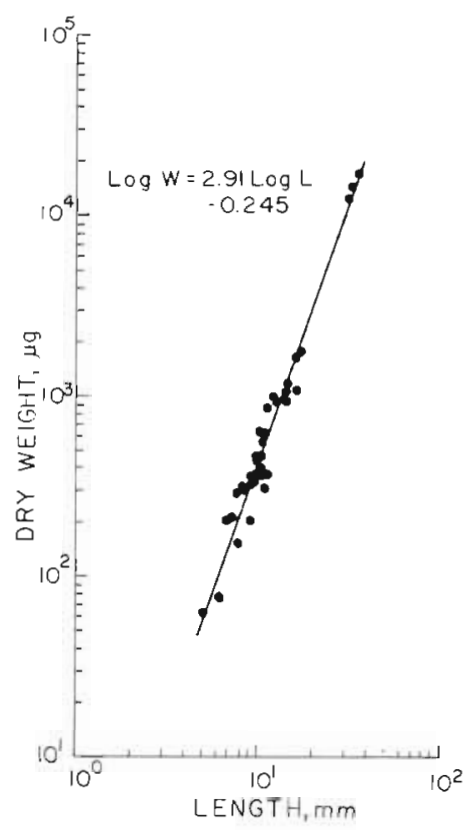

Fig. 4. Ammodytes americanus. Length(L)-dry weight(W) relation. $N=35$ copepod biomass. The 3 most common species in the Sound during that time of year are Temora longicornis, Acartia hudsonica and Pseudocalanus sp., which were most abundant between 5 and $15 \mathrm{~m}$ (Peterson 1985).

\section{Gut content analyses}

The major food items of sand lance larvae consisted of phytoplankton and various developmental stages of copepods (Table 2). Larvae $<8 \mathrm{~mm}$ were either empty or contained only phytoplankton. Larvae 8 to $11.9 \mathrm{~mm}$ consumed copepod nauplii of Temora longicornis, Acartia hudsonica and Pseudocalanus sp. Larvae 12 to $18.9 \mathrm{~mm}$ consumed both nauplii and copepodites,
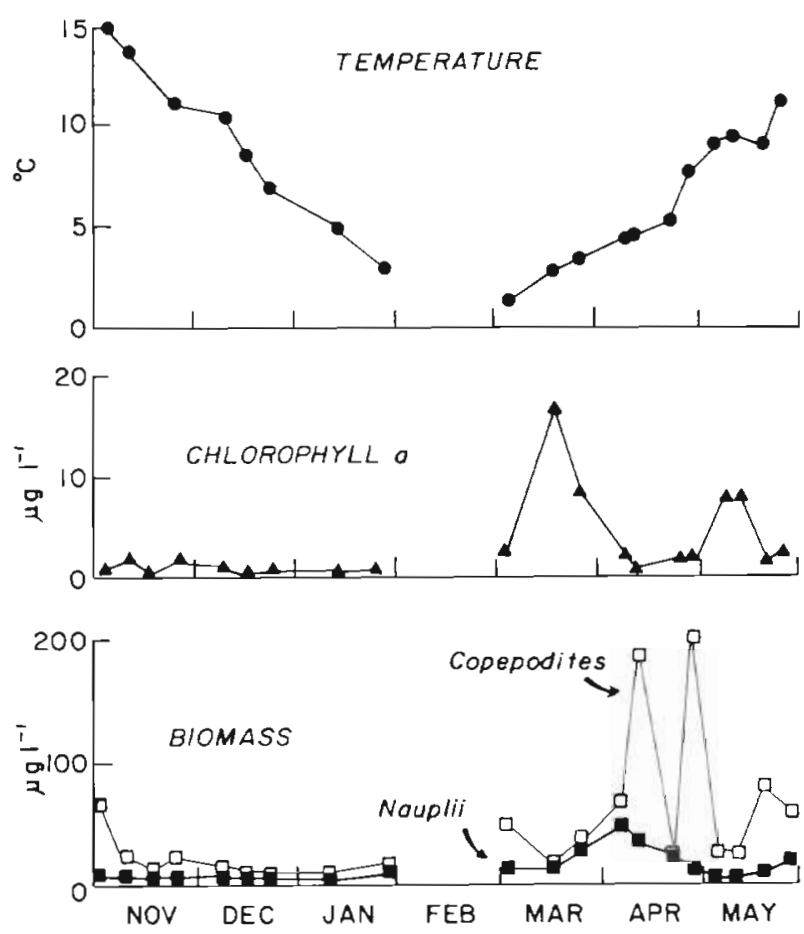

Fig. 5. Temperature, chlorophyll a concentrations and biomass (dry weight) of all species of copepod nauplii and copepodites dunng winter and spring 1982-83 at depth $5 \mathrm{~m}$ at Stn B

whereas larvae 19 to $23.9 \mathrm{~mm}$ consumed a greater weight of copepodites and A. hudsonica adults than of nauplii. Those $\geq 24 \mathrm{~mm}$ fed almost exclusively on adult $A$. hudsonica. Minor items in the diet of sand lance larvae include copepod, invertebrate and fish eggs, and barnacle cyprids. The larvae collected at dawn on 8 May 1985 were empty and were not included in Table 2.

Average total dry weight of the gut contents for larvae of different lengths was calculated for those larvae whose guts were not empty (Fig. 6). The aver- 
age dry weight of the gut contents in $\mu \mathrm{g}\left(\mathrm{W}_{\mathrm{g}}\right)$, vs the length of the larvae in mm (L) followed a logarithmic function:

$$
\log W_{g}=4.51 \log L-4.64
$$

Using the length-weight relation and the weight of the gut contents $v$ s the length of the larvae, the percent of the larval body weight consisting of gut contents was calculated for $1 \mathrm{~mm}$ size classes of larvae. They ranged from 0.05 to $2.64 \%$ with an average of $0.56 \%$. There were no obvious trends in the relation of percent larval body weight consisting of gut contents versus the total dry weight of the larvae.

\section{Feeding selectivity}

Feeding selectivities on different species of copepods were calculated using the Ivlev index. The electivity indices for nauplii showed that in 1983, the larvae selected for Temora longicornis and against Acartia hudsonica (Table 3a). In general, the larvae selected for $T$. longicornis copepodites (Table 3b). During March and early April, A. hudsonica adult females were strongly selected against, but were positively selected for by the end of April. In selective feeding studies conducted in the laboratory, using copepod nauplii, the larvae did not show a preference for either T. longicornis or A. hudsonica nauplii (Fig. 7).

Table 2. Ammodytes americanus. Gut contents of 165 larvae collected in Long Island Sound. Larvae with empty guts were not included in the calculations. Data are average dry weight $(\mu \mathrm{g})$ of prey items for each size group. "Weights $<0.005 \mu \mathrm{g}$; - unknown weights. $\mathrm{N}=$ naupliar stage and $\mathrm{C}=$ copepodite stage of copepods. 'Acartia adults' are nol differentiated by sex so dry weight is an average. Weights for prey items were taken from Haris \& Paffenhöfer (1976), Durbin \& Durbin (1978) and Peterson (unpubl.)

\begin{tabular}{|c|c|c|c|c|c|}
\hline Size in $\mathrm{mm}$ & $<8.0$ & $8-11.9$ & $12-18.9$ & $19-23.9$ & $\geq 24$ \\
\hline Number of larvae examined & 15 & 37 & 84 & 16 & 13 \\
\hline$\%$ with phytoplankton & 80 & 22 & 0 & 0 & 0 \\
\hline$\%$ empty & 20 & 13 & 2 & 0 & 0 \\
\hline Temora egg $(0.1 \mu \mathrm{g})$ & & & 0.23 & 0.05 & • \\
\hline Temora N1-5 $(0.25)$ & & 0.52 & 0.90 & 0.47 & \\
\hline Temora N6 $(0.7)$ & & 0.15 & 0.31 & 0.76 & 0.03 \\
\hline Temora C1 (1.2) & & & 0.57 & 1.08 & \\
\hline Temora C2 (2.3) & & & 0.46 & 1.36 & \\
\hline Temora C3 $(4,2)$ & & & 0.30 & 1.34 & \\
\hline \multicolumn{6}{|l|}{ Temora C4 (7.7) } \\
\hline Temora C5 (13.2) & & & & 1.76 & 0.94 \\
\hline Temora adult $(28.0)$ & & & & & 4.00 \\
\hline Acartia egg (0.1) & & & & 0.05 & - \\
\hline Acartia N1-5 $(0.25)$ & & 0.07 & 0.13 & 0.06 & \\
\hline Acartia No $(0.3)$ & & 0.01 & 0.01 & & \\
\hline Acartia C1 $(0.6)$ & & & 0.07 & & 0.17 \\
\hline Acartia C2 (0.9) & & & 0.04 & 0.02 & \\
\hline Acartia C3 (1.5) & & & 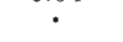 & 0.60 & 0.13 \\
\hline Acartia C4 (2.4) & & & 0.75 & 0.48 & \\
\hline Acartia C5 (4.3) & & & 1.35 & & 2.10 \\
\hline Acartia male (5.8) & & & 0.50 & 0.77 & \\
\hline Acartia female (9.6) & & & 1.65 & 10.88 & 51.20 \\
\hline Acartia adult $(7.7)$ & & & 2.50 & 3.22 & 29.23 \\
\hline Pseudocalanus N1-5 (0.25) & & 0.02 & 0.03 & 0.10 & \\
\hline Pseudocalanus N6 $(0.3)$ & & & & 0.02 & \\
\hline Pseudocalanus C3 (4.6) & & & 0.04 & & \\
\hline Pseudocalanus adult (16.7) & & & 0.48 & & \\
\hline Centropages C4 (7.7) & & & & 0.17 & \\
\hline Centropages male $(20.0)$ & & & & & 0.71 \\
\hline Unidentified N1-5 $(0.25)$ & & & & 0.02 & \\
\hline 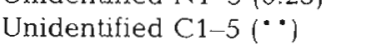 & & & $\cdots$ & $\cdots$ & \\
\hline Unknown copepod egg (0.1) & & 0.01 & 0.01 & & \\
\hline Invertebrate egg $\left({ }^{*}\right)$ & & $\cdots$ & $\cdots$ & & \\
\hline Fish egg $(\cdots)$ & & & $\cdots$ & & $\cdots$ \\
\hline Barnacle cyprid (10.0) & & & & & 0.71 \\
\hline
\end{tabular}




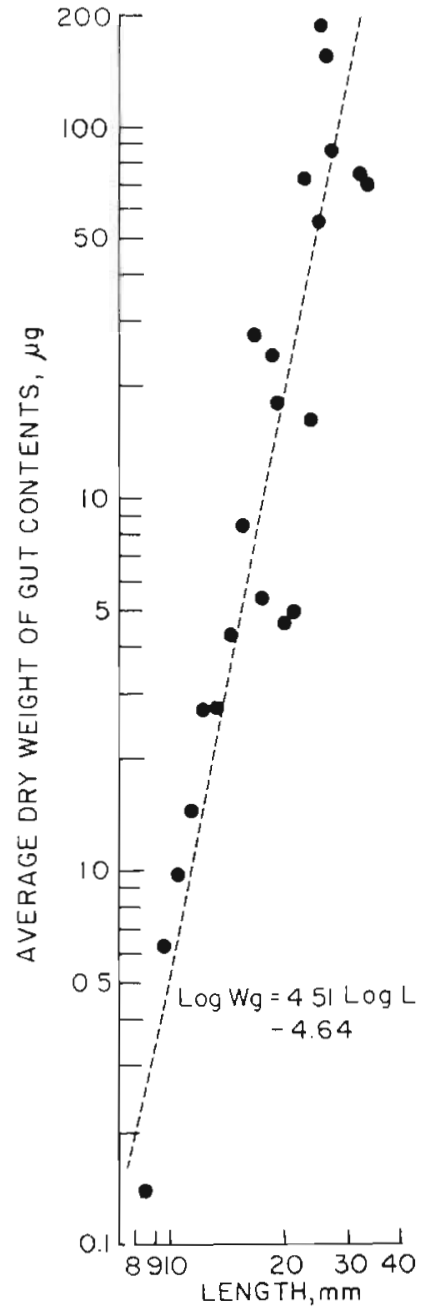

Fig. 6. Ammodytes americanus. Average dry weight of gut contents $\left(W_{\mathrm{g}}\right)$ vs length of larvae $(\mathrm{L})$

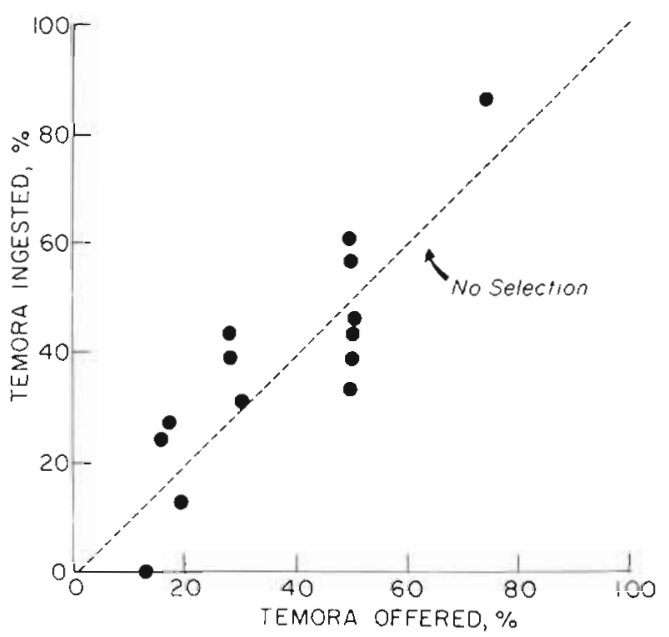

Fig. 7. Ammodytes americanus. Selective feeding experiment in the laboratory using nauplii of Temora longicornis and Acartia hudsonica. Larvae ranged from 7 to $11.5 \mathrm{~mm}$, naupliar densities were 5 to $2001^{-1}$ and temperature was $7^{\circ} \mathrm{C}$. The line of slope equal to 1 is line of no selection

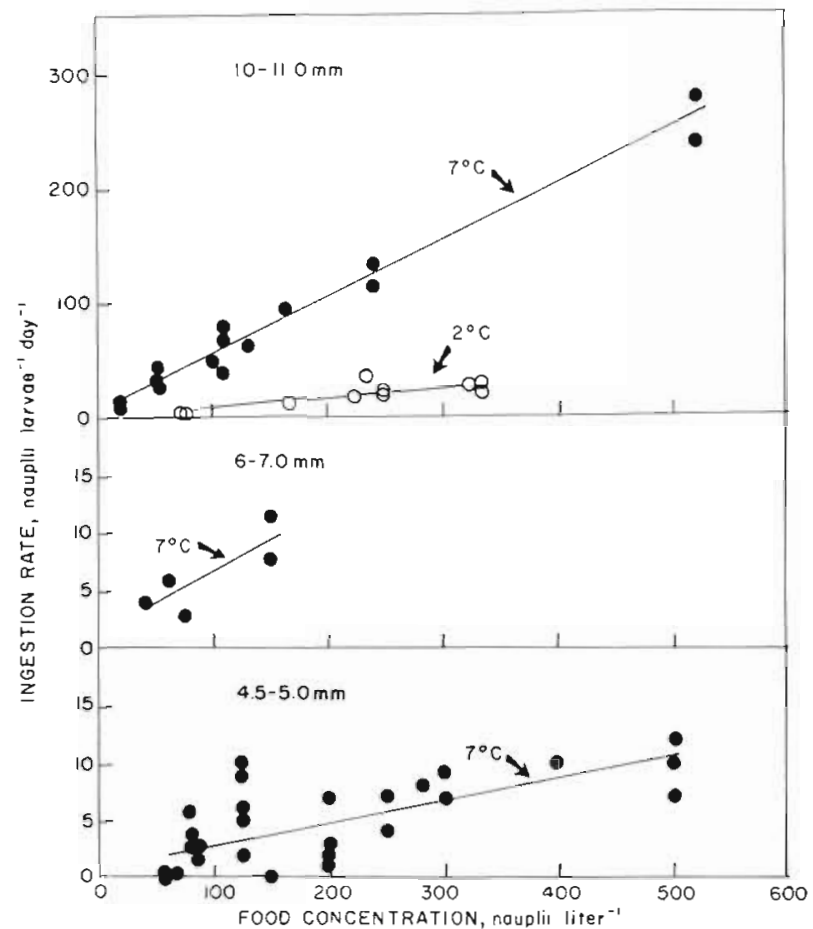

Fig. 8. Ammodytes americanus. Ingestion rates of individual larvae of size groups 4.5 to $5.0,6$ to 7.0 , and 10 to $11.0 \mathrm{~mm}$ in length in the laboratory. Larvae 10 to $11.0 \mathrm{~mm}$ were studied at 2 temperatures. All larvae were fed a mixture of Temora longicornis and Acartia hudsonica nauplii

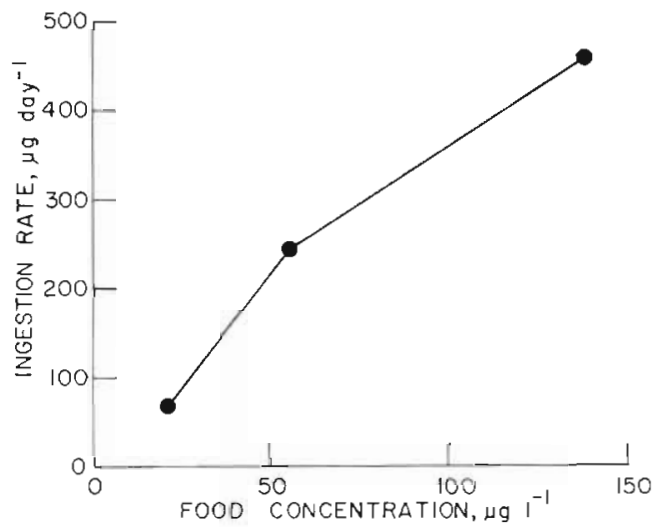

Fig. 9. Ammodytes amencanus. Ingestion rate of $21 \mathrm{~mm}$ larva The prey items consisted of naupliar through adult stages of Temora longicornis and Acartia hudsonica

\section{Feeding behavior}

Observations of live larvae in the laboratory showed that their feeding behavior changed with ontogeny. Larvae less than $9 \mathrm{~mm}$ remained in a head-down position most of the time, swimming only occasionally. Feeding was not observed. Larvae greater than $10 \mathrm{~mm}$ were more active swimmers. They assumed an S-pos- 


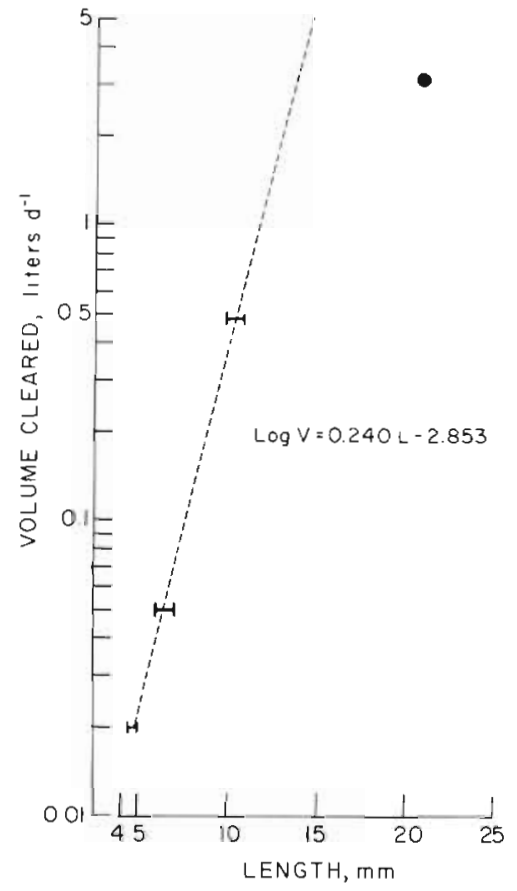

Fig. 10. Ammodytes americanus. Volume cleared (V) for 3 size groups 4.5 to $5.0,6$ to 7.0 , and 10 to $11.0 \mathrm{~mm}$ larvae $(\mathrm{L})$ fed copepod nauplii. Closed circle indicates volume cleared for the $21 \mathrm{~mm}$ larva fed naupliar through adult stages ture while maintaining their orientation to a moving prey, never struck at a prey more than once, and often seemed only to observe a potential prey item.

\section{Feeding rates}

Feeding rates were directly related to the size of the larvae, the water temperature, and the concentration of nauplii (Fig. 8). At $7^{\circ} \mathrm{C}$, larvae 4.5 to $5.0 \mathrm{~mm}$ consumed 2 to 11 nauplii $\mathrm{d}^{-1}$ at prey densities of 50 to $500 \mathrm{l}^{-1}$.

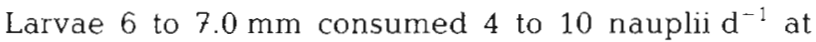
prey densities of 40 to $150 \mathrm{l}^{-1}$. Larvae 10 to $11.0 \mathrm{~mm}$ consumed 15 to 265 nauplii $\mathrm{d}^{-1}$ at prey densities of 20 to 525 nauplii $\mathrm{l}^{-1}$. At $2^{\circ} \mathrm{C}$, prey consumption by larvae 10 to $11.0 \mathrm{~mm}$ was reduced to 5 to 30 nauplii $\mathrm{d}^{-1}$ at prey densities of 65 to 325 nauplii $\mathrm{l}^{-1}$. An asymptotic ingestion rate was not reached over the domain of the concentrations of nauplii used.

When offered a mixture of prey sizes, including nauplii, copepodites and adults of Temora longicornis and Acartia hudsonica, the $21 \mathrm{~mm}$ larva consumed organisms weighing from 0.25 to $13.2 \mu$ dry weight. In general, the dry weight of food consumed seems to increase linearly with the concentration of food offered over the domain 20 to $140 \mu \mathrm{g} \mathrm{l}^{-1}$ (Fig. 9).

Table 3. Ammodytes americanus. Ivlev electivity indices. Tl: Temora longicornis; Ah: Acartia hudsonica; Ps: Pseudocalanus sp. Positive numbers $=$ selection for a species; negative numbers = selection against; zero = neutral selectivity. All larvae taken at Stn B. (A) Selectivity among different species of nauplii. (B) Selectivity of larger larvae among copepodites and adult females of A. hudsonica and $T$. longicornis

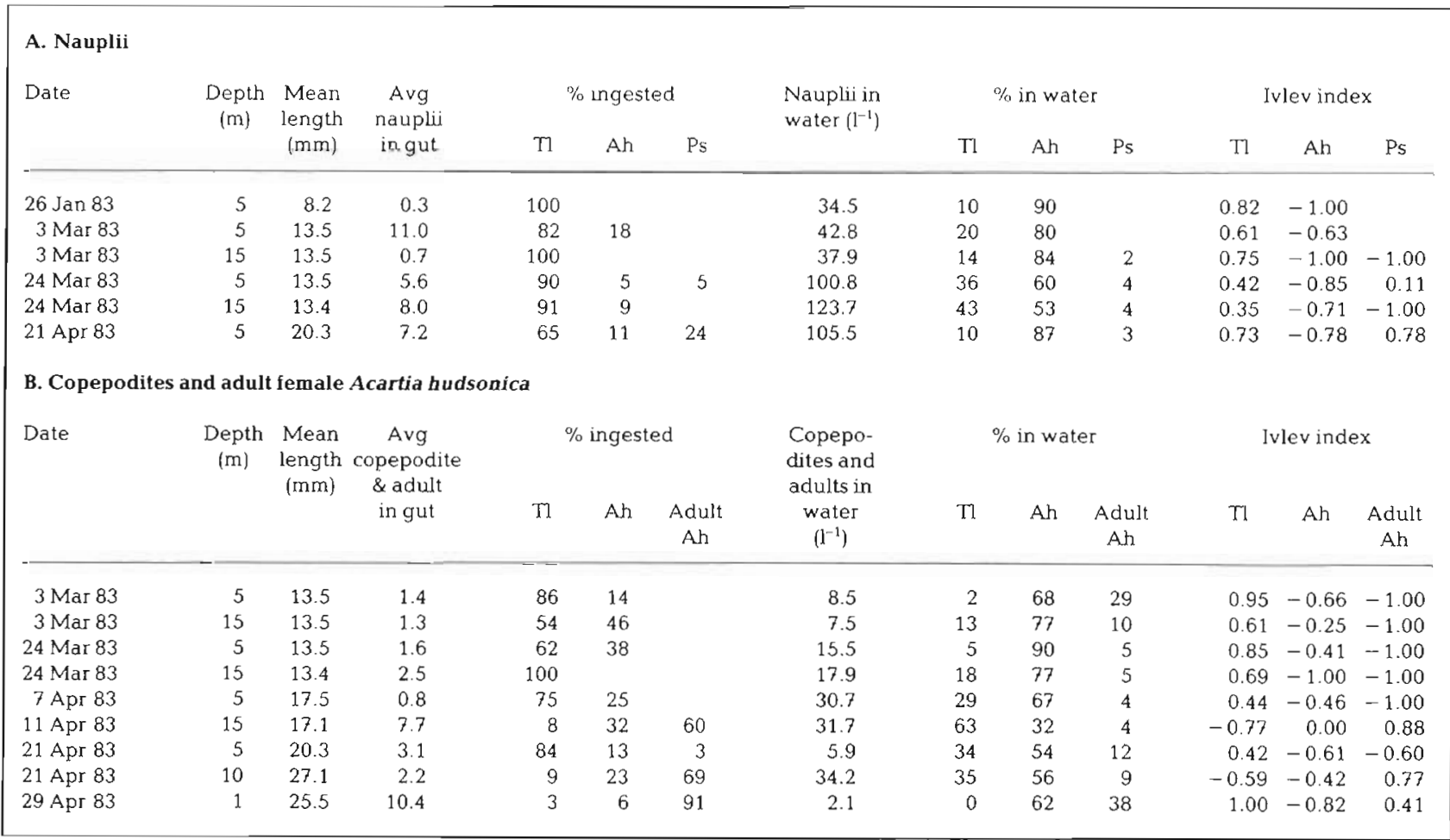


The slopes of the lines in Fig. 8 and 9 are equivalent to the volume of water cleared by the larvae, in units of $\mathrm{l} \mathrm{d}^{-1}$. For larvae 4.5 to $5.0,6$ to $7.0,10$ to 11.0 , and $21 \mathrm{~mm}$, the slopes at $7^{\circ} \mathrm{C}$ were $0.02,0.05,0.48$, and $3.2 \mathrm{l} \mathrm{d}^{-1}$, respectively. Clearance rates were plotted against the length of the larvae (Fig. 10). The volume cleared for the 3 size classes of smaller larvae followed a logarithmic function:

$$
\log V=0.240 \mathrm{~L}-2.853
$$

where $\mathrm{V}=$ volume of water cleared in $\mathrm{ld}^{-1} ; \mathrm{L}=$ length of the larvae in $\mathrm{mm}$. The volume cleared for the $21 \mathrm{~mm}$ larva fell below the predicted value.

The frequency of gut fillings under natural conditions was estimated using the ingestion rate data from the laboratory and estimates of prey densities in the field. At prey densities of $25 \mu \mathrm{g}$ dry weight of nauplii $1^{-1}$ (approximately 100 nauplii $\mathrm{l}^{-1} ;$ typical of Long Island Sound during March-April) a $10.5 \mathrm{~mm}$ larva at $7^{\circ} \mathrm{C}$ would consume approximately $12 \mu \mathrm{g}$ of prey biomass $\mathrm{d}^{-1}$. The gut contents of field-collected larvae indicated an gut capacity of $0.92 \mu \mathrm{g}$ (from Eq. 3). These larvae would, therefore, fill their guts 13 times $\mathrm{d}^{-1}$. Ryland (1964) suggested that sand lance larvae feed only during daylight, and the present study reinforces his hypothesis. Assuming 10 to $12 \mathrm{~h}$ of daylight, larval gut evacuation times would range from 45 to $55 \mathrm{~min}$. These times could be somewhat longer if the estimates of gut capacity is biased downward due to the possibility of some regurgitation during collection.

\section{Impact of larvae on zooplankton populations}

Variables influencing the feeding rate of sand lance larvae (size of larvae, temperature, and food concentration) were examined, and the impact that the larvae have on copepod nauplii was calculated. Calculations were carried out for several days in March. During that month, copepod nauplii and sand lance larvae are abundant, so it is the time when the larvae are expected to have the greatest impact on the copepod nauplii. It is also a time when a majority of the larvae are within the size range which feed primarily on copepod nauplii. The calculations for 24 March 1982 (Table 4) show that approximately 380 nauplii $\mathrm{m}^{-3}$ were consumed by larvae. Given a density of 140000 nauplii $\mathrm{m}^{-3}$, and an instantaneous net growth rate of $0.02 \mathrm{~d}^{-1}$ (calculated from observed change in biomass at the time; Peterson unpubl.), 2828 nauplii $\mathrm{m}^{-3} \mathrm{~d}^{-1}$ would be produced. The larvae, therefore, consumed $13.4 \%$ of the total number of copepod nauplii produced per day, but only $0.27 \%$ of the standing stock. The results of all other dates indicated that less than $10 \%$ of the daily production of copepod nauplii was consumed. Given this estimate of production is very conservative, the actual loss due to fish larvae is probably lower.

\section{DISCUSSION}

The diet of American sand lance Ammodytes americanus larvae consists initially of phytoplankton, but following the spring bloom, the diet shifts to primarily nauplius through adult stages of copepods, as is typical of most marine fish larvae (Hunter 1981). The dominant copepods consumed were Temora longicornis and Acartia hudsonica which is in agreement with an earlier study of sand lance larval diets in Long Island Sound (Covill 1959). Lebour (1918, 1919) and Ryland (1964) also reported phytoplankton or 'green food remains' and various stages of copepods as the most common food items of A. americanus, A. lanceolatus, A. marianus, and A. tobianus.

Small sand lance larvae appear to be opportunistic

Table 4. Ammodytes americanus, 24 Mar 1982. Calculations showing impact of sand lance larvae on copepod nauplii in Long Island Sound using consumption rates obtained in the laboratory and densities of larvae in the field. Total nauplii consumed was $379 \mathrm{~m}^{-3} \mathrm{~d}^{-1}$ at a prey density of 140 nauplii $\mathrm{l}^{-1}$

\begin{tabular}{|c|c|c|c|c|}
\hline $\begin{array}{l}\text { Length } \\
(\mathrm{mm})\end{array}$ & $\begin{array}{l}\text { Volume cleared } \\
\qquad\left(\mathrm{l} \mathrm{d}^{-1}\right)\end{array}$ & $\begin{array}{l}\text { Nauplii consumed } \\
\left(\text { no. larva } e^{-1} \mathrm{~d}^{-1}\right)\end{array}$ & $\begin{array}{c}\text { Density } \\
\text { (larvae } \mathrm{m}^{-3} \text { ) }\end{array}$ & $\begin{array}{l}\text { Nauplii consumed } \\
\left(\text { no. } \mathrm{m}^{-3} \mathrm{~d}^{-1}\right)\end{array}$ \\
\hline 6.5 & 0.05 & 7.1 & 0.08 & 0.6 \\
\hline 7.5 & 0.09 & 12.5 & 0.03 & 0.4 \\
\hline 8.5 & 0.15 & 21.5 & 0.09 & 1.9 \\
\hline 9.5 & 0.2 & 37.4 & 0.15 & 56 \\
\hline 10.5 & 0.4 & 65.3 & 0.32 & 20.9 \\
\hline 11.5 & 0.8 & 113.0 & 0.23 & 26.0 \\
\hline 12.5 & 1.4 & 196.4 & 0.17 & 33.4 \\
\hline 13.5 & 2.4 & 341.3 & 0.19 & 64.9 \\
\hline 14.5 & 4.2 & 593.0 & 0.12 & 71.2 \\
\hline 15.5 & 7.3 & 1030.7 & 0.15 & 154.6 \\
\hline
\end{tabular}


feeders. In Long Island Sound, larvae $<8 \mathrm{~mm}$ feed primarily on phytoplankton, but in the laboratory they will readily consume copepod nauplii. Field-collected larvae probably never contained nauplii because there were few nauplii available during December and January when $<8 \mathrm{~mm}$ larvae occur. Covill (1959) found some copepod nauplii in the guts of larvae of this size range but noted that nauplii were found in $20 \%$ fewer guts during winter than during spring.

An increase in size and range of size of prey items with increasing size of larvae has been noted for other species by Laurence (1977), Last (1978), Gamble et al. (1981), Hunter (1981), Cohen \& Lough (1983), Govani et al. (1983), Kane (1984), and Peterson \& Ausubel (1984). This means that larger larvae which require more food are able to clear additional items, including larger items, from a unit volume than smaller larvae. In the laboratory experiments a $21 \mathrm{~mm}$ larva consumed not only nauplii but copepodites and adult copepods. All stages were also found in the guts of field-collected larvae. Larvae $\geq 24 \mathrm{~mm}$ consumed adult copepods, which are the same prey items consumed by adult sand lance (McKown 1984).

For sand lance larvae, the type of prey item consumed was closely related to their swimming ability. Prolarval behavior was consistent with observations of larval anchovies Engraulis ringens and E. mordax by Hunter (1972) and Ware et al. (1981), respectively. The passive, head-down orientation is an indicator of poor swimming ability. At this stage, the larvae feed on phytoplankton and a few copepod nauplii which are small and more quiescent. Larvae $>9 \mathrm{~mm}$ are more active hunters adding copepodites which are much stronger swimmers than nauplii to their diet. In addition, they assume an S-posture while they observe their prey. Anatomical changes begin to take place in fish of this size. Richards (1965) reported that Ammodytes americanus begin to develop dorsal and anal fin rays at 9 to $12 \mathrm{~mm}$ in length, suggesting a change in swimming ability. Larvae of approximately $21 \mathrm{~mm}$ captured faster swimming prey, including older copepodites of Temora longicornis and older copepodites and adults of Acartia hudsonica, along with nauplii of both species. Dorsal fin rays develop forward of the vent in larvae ranging from 15 to $20 \mathrm{~mm}$ (Richards 1965), suggesting another increase in swimming ability. When larvae reach $24 \mathrm{~mm}$, they begin to feed primarily on adult copepods. This is also the size range in which the vertebral column forms (Sarah $W$. Richards, pers. comm.). The increase in size of the prey items with larval ontogeny may also be influenced by the increase in mouth width, as discussed by Hunter (1981); however, for sand lance, ontogenetic changes in swimming ability and hunting tactics may also explain the occurrence of larger prey in their diets.
Temperature directly affected the daily ration of sand lance larvae. An increase of water temperature from 2 to $7^{\circ} \mathrm{C}$ resulted in a 6 -fold increase in the daily ration of the 10 to $11.0 \mathrm{~mm}$ larvae from 7 to 48 nauplii $\mathrm{d}^{-1}$ at 100 nauplii $\mathrm{l}^{-1}$. Other larval fish, such as Atlantic menhaden Brevoortia tyrannus, spot Leiostomus xanthurus, and pinfish Lagodon rhomboides, which occur at higher temperatures $\left(15\right.$ to $\left.17^{\circ} \mathrm{C}\right)$, have greater daily rations of 3.5 to $9.0 \%$ of their body weight (Kjelson et al. 1975). Atlantic mackerel Scomber scombrus larvae, which also occur over a higher range of temperature than do sand lance, have daily rations an order of magnitude greater than those of sand lance (Peterson \& Ausubel 1984). It is important, therefore, that the ingestion rates of organisms be studied over the complete range of temperatures to which they are exposed in nature. A temperature change of only a few degrees could considerably alter calculations of the feeding impact.

In feeding experiments, the ingestion rate of sand lance larvae showed a positive linear response to prey concentration. There was no evidence of an Ivlev-type response (Ivlev 1961), as was found for larvae of winter flounder Pseudopleuronectes americanus (Laurence 1977), bay anchovy Anchoa mitchilli, lined sole Achirus lineatus, and sea bream Archosarus rhomboidalis (Houde \& Schekter 1980). Those larvae, however, only reached asymptotic ingestion rates at prey densities much higher both than those in this study and than natural conditions.

When the daily ration obtained in the laboratory at food concentrations that are typical of natural concentrations is calculated and compared to the ration needed to satisfy daily growth requirements, the larvae appear to be starving. As an example, a $10.5 \mathrm{~mm}$ sand lance larva feeding in the laboratory on 100 nauplii $1^{-1}$ at $7^{\circ} \mathrm{C}$ would consume $11.6 \mu \mathrm{g}$ dry weight of nauplii $\mathrm{d}^{-1}$ (from Fig. 8). At $7^{\circ} \mathrm{C}$ the instantaneous growth rate of larvae was $0.048 \mathrm{~d}^{-1}$ in the laboratory (Smigielski et al. 1984) and $0.04 \mathrm{~d}^{-1}$ in nature (this study, calculated from March-April). This is equivalent to growths of 25 and $21 \mu \mathrm{g}$ dry weight $\mathrm{d}^{-1}$, respectively. Assuming a gross growth efficiency of $30 \%$ (a value similar to that found for winter flounder larvae by Laurence 1977), a $10.5 \mathrm{~mm}$ larva must consume 60 to $70 \mu \mathrm{g}$ dry weight $\mathrm{d}^{-1}$ to fulfill metabolic requirements, far greater than the $12 \mu \mathrm{g} \mathrm{d}^{-1}$ measured in the laboratory. For 4.5 and $6.5 \mathrm{~mm}$ sand lance larvae, the discrepancy between measured and calculated daily ration was 9 -fold and for a $21 \mathrm{~mm}$ larva, 3-fold. Laurence (1977), raising winter flounder larvae at $8^{\circ} \mathrm{C}$, found that they survived less than 2 wk when supplied with 100 nauplii $1^{-1}$, but bay anchovy, lined sole, and sea bream grew at that prey concentration (Houde \& Schekter 1981). These larvae, however, were maintained at 26 to $28^{\circ} \mathrm{C}$, and 
Table 5. Ammodytes americanus. Estimate of percent of copepod biomass removed by sand lance larvae assuming that individual larvae consume one-third of their body weight $\mathrm{d}^{-1}$ Percent removed for larvae collected in Mar was calculated assuming they feed only on nauplii and those in Apr for only copepodites

\begin{tabular}{|c|c|c|c|c|c|}
\hline \multirow[t]{2}{*}{ Date } & \multirow[t]{2}{*}{ Depth (mm) } & \multirow{2}{*}{$\begin{array}{l}\text { Larval biomass } \\
\qquad\left(\mu \mathrm{gl}^{-1}\right)\end{array}$} & \multicolumn{2}{|c|}{ Copepod biomass ( $\mu \mathrm{g} \mathrm{I}^{\prime}$ ) } & \multirow[t]{2}{*}{$\%$ removed } \\
\hline & & & Nauplii & Copepodites & \\
\hline 3 Mar 83 & 5 & 1.7 & 10.6 & 47.2 & 5.30 \\
\hline $3 \operatorname{Mar} 83$ & 15 & 0.3 & 9.3 & 59.8 & 1.10 \\
\hline $24 \mathrm{Mar} 83$ & 5 & 0.8 & 23.3 & 34.8 & 1.1 .0 \\
\hline 24 Mar 83 & 15 & 0.1 & 12.5 & 84.3 & 0.27 \\
\hline 7 Apr 83 & 5 & 1.8 & 54.8 & 65.9 & 0.90 \\
\hline 11 Apr 83 & 15 & 0.1 & 17.6 & 148.6 & 0.00 \\
\hline 21 Apr 83 & 5 & 3.0 & 25.2 & 24.0 & 4.10 \\
\hline 21 Apr 83 & 10 & 0.2 & 18.1 & 59.3 & 0.11 \\
\hline 29 Apr 83 & 1 & 1.7 & 14.3 & 199.5 & 0.28 \\
\hline
\end{tabular}

consumed 5 times the number of prey consumed by sand lance larvae of a similar size at the same prey concentration. The difference between measured and calculated ration for small sand lance $(<8 \mathrm{~mm})$ may be explained by our observation that, in nature, they feed primarily on phytoplankton which is not accounted for in our calculations. The larger larvae may encounter microscale patches of copepod nauplii and copepodites. Alternatively, feeding behavior in the laboratory may not, because of containment effects, accurately represent feeding behavior in nature.

The feeding impact that sand lance larvae have on copepod biomass seems to be small. The calculations in Table 4 indicate that in March, when the biomass of sand lance was highest, less than $1 \%$ of the biomass of copepod nauplii was consumed. However, as suggested above, we may have underestimated the daily ration of sand lance by a factor of 5 . In Table 5, we recalculate the impact that the sand lance larvae have on copepod biomass, assuming that the fish consume one-third of their body weight per day. The results show that the fish removed at most an average of $1.5 \%$ of the copepod biomass per day in March and April. This is similar to calculations given by Cushing (1983) for larval hake and plaice, Dagg et al. (1984) for walleye pollock and Peterson \& Ausubel (1984) for Atlantic mackerel larvae.

Acknowledgements. This research was supported in part by the New York State Sea Grant Institute and Sigma-Xi, Scientific Research Society. We thank Dr. Linda E. Duguay, Thomas Johnson, Dr. George C. Williams and Dr. Sarah W Richards for helptul comments on this manuscript and earlier versions.

\section{LITERATURE CITED}

Cohen, R. E., Lough, R. G. (1983). Prey field of larval herring Clupea harengus on a contmental shelf spawning area. Mar. Ecol. Prog. Ser. 10: 211-222

Covill, R. W (1959). Food and feeding habits of larvae and post-larvae of Ammodytes americanus. Bull. Bingham oceanogr. Coll. 17: 125-146

Cushing, D. H. (1983). Are fish larvae too dilute to affect the density of their food organisms? J. Plankton Res. 5: $847-854$

Dagg, M. J., Clarke, M. E., Nishiyama, T., Smith, S. L. (1984), Production and standing stock of copepod naupiii, food items for larvae of the walleye pollock Theragra chalcogramma in the southeastern Bering Sea. Mar. Ecol. Prog. Ser. 19: 7-16

Durbin, E. G., Durbin, A. G. (1978). Length and weight relationships of Acartia clausi from Narragansett Bay, Rhode Island. Limnol. Oceanogr. 23: 958-969

Gamble, J. C., MacLachlan, P., Nicoll, N. T., Baxter, J. G. (1981). Growth and feeding of Atlantic herring larvae reared in large plastic enclosures. Rapp. P.-v. Réun. Cons. int. Explor Mer. 178: 121-134

Govani, J. J., Hoss, D. E., Chester, A. J. (1983). Comparative feeding of three species of larval fishes in the Northern Gulf of Mexico: Brevoortia patronus, Leiostomus xanthurus and Micropogonias undulatus. Mar. Ecol. Prog. Ser. 13: $189-199$

Harris, R. P., Paffenhofer, G.-A. (1976). Feeding, growth and reproduction of the marine planktonic copepod Temora longicornis Müller. J. mar, biol. Ass. U.K. 56: 675-690

Houde, E. D., Schekter, R. C. (1980). Feeding by marine fish larvae: developmental and functional response. Environ. Biol. Fish. 5: 315-334

Houde, E. D., Schekter, R. C. (1981). Growth rates, rations and cohort consumption of marine fish larvae in relation to prey concentration. Rapp. P.-v. Réun. Cons. int. Explor. Mer 178: 441-453

Hunter, J. R. (1972). Swimming and feeding behavior of larval. anchovy, Engraulis mordax. Fish. Bull. U.S. 70: 821-838

Hunter, J. R. (1981). Feeding ecology and predation of marine fish larvae. In: Lasker, R. (ed.) Marine fish larvae: metamorphosis, ecology and relation to fisheries. University of Washington Press, Seattle

Ivlev, I. S. (1961). Experimental ecology of the feeding of fishes. Yale Univ. Press, New Haven

Kane, J. (1984). The feeding habits of co-occurring cod and haddock larvae from Georges Bank. Mar. Ecol. Prog. Ser. 16: $9-20$

Kjelson, M. A., Peters, D. S., Thayer, G. W., Johnson, G. N. (1975). The general feeding ecology of postlarval fishes in the Newport River estuary. Fish. Bull. U.S. 73: 137-144

Last, J. M. (1978). The food of three species of gadid larvae in 
the English Channel and southern North Sea. Mar. Biol. 48: $377-386$

Laurence, G. C. (1977). A bioenergetic model for the analysis of feeding and survival potential of winter flounder, Pseudopleuronectes amencanus, larvae during the period from hatching to metamorphosis. Fish. Bull. U.S. 75: 529-546

Lebour, M. V. (1918). The food of post-larval fish. J. mar. biol. Ass. U.K. 11. 433-479

Lebour, M. V (1919). The food of post-larval fish. Part II. J. mar. biol. Ass. U.K. 12: 22-47

Mckown, K. A. (1984). Age, growth, and feeding ecology of sand lance, Ammodytes americanus, in Long Island Sound. M.S. thesis, State Univ. of New York, Stony Brook

Monteleone, D. M. (1984). Year to year variations in abundance and feeding ecology of sand lance, Ammodytes americanus, larvae in Long Island Sound. M.S. thesis, State Univ. of New York, Stony Brook

Peterson, W. T. (1985). Abundance, age structure and in situ egg production rates of the copepod Temora longicornis in Long Island Sound, New York. Bull. mar. Sci. 37: 726-738

Peterson, W. T (1986). The effects of seasonal stratification on plankton dynamics in Long Island Sound. In: Bowman, M., Yentsch, C., Peterson, W. (ed.) Tidal mixing and plankton dynamics. Springer Verlag, Berlin, Lecture Notes Series (in press)

Peterson, W. T., Ausubel, S. J. (1984). Diets and selective feeding by larvae of Atlantic mackerel Scomber scombrus on zooplankton. Mar. Ecol. Prog. Ser 17: 65-75

Reay, P. J. (1970). Synopsis of biological data on North Atlan- tic sand eels of the genus Ammodytes (A. tobianus, $A$. dubius, $A$ americanus and $A$. marianus). FAO Fish. Synopsis No. 82

Richards, S. W. (1965). Description of the postlarvae of the sand lance (Ammodytes) from the east coast of North America. J. Fish. Res. Bd Can. 22: 1313-1317

Riley, G. A (1956). Oceanography of Long Island Sound, 1952-1954. II. Physical oceanography. Bull. Bingham oceanogr Coll. 15: 15-46

Riley, G. A. (1967). The plankton of estuaries. In: Lauff, G. H (ed.) Estuaries. Washington AAAS Publication No. 83

Riley, G. A., Conover, S. A. (1956). Oceanography of Long Island Sound, 1952-1954. III. Chemical Oceanography. Bull. Bingham oceanogr. Coll. 15: 47-61

Ryland, J. S. (1964). The feeding of plaice and sand-eel larvae in the southerm North Sea. J. mar. biol. Ass. U.K. 44: 343-364

Smigielski, A. S., Halavik, $\Upsilon$ A., Buckley, L. J., Drew, S. M., Laurence, G. C. (1984). Spawning, embryo development and growth of the American sand lance Ammodytes americanus in the laboratory. Mar Ecol. Prog. Ser. 14: 287-292

Vishniac, H. G., Riley, G. A. (1961). Cobalamin and thiamine in Long Island Sound: Patterns of distribution and ecological significance. Limnol. Oceanogr. 6: 36-41

Ware, D. M., de Mendiola, B. R., Newhouse, D. S. (1981). Behavior of first-feeding Peruvian anchoveta larvae, Engraulis ringens. Rapp. P.-v. Réun. Cons. int. Explor. Mer 178: $467-474$

This article was presented by Dr. R. Lasker; it was accepted for printing on March 4, 1986 